\title{
Challenges and Opportunities of Management Accounting in Iran Industries
}

\author{
Fatemeh Baghiyan ${ }^{1,2}$ \\ ${ }^{1}$ Department of accountancy, Azad University of Gazvin, Gazvin baragin, Iran \\ ${ }^{2}$ Nuclear Science and Technology Research Institute, Plasma Physics and Nuclear Fusion Research School, A.E.O.I., Tehran, Iran
}

\section{Email address:}

parbag@yahoo.com

\section{To cite this article:}

Fatemeh Baghiyan. Challenges and Opportunities of Management Accounting in Iran Industries. International Journal of Economic Behavior and Organization. Vol. 1, No. 6, 2013, pp. 56-60. doi: 10.11648/j.ijebo.20130106.11

\begin{abstract}
In this article, we have studied recent changes in management accounting and respected disabuses which is the most important challenges and opportunities led to advance in management accounting. Management accounting extended by emphasis on accounting in three major fields as: 1) Activity accounting; 2) Strategic management accounting; 3) Accounting for advanced manufacturing technology (AAMT). These three major fields promote future management accounting and refresh it. Consequently, as management accounting can go on extended services to various commercial, industrial and governmental unit scan adapt future management accounting with new technological and management accounting. Management accounting including activity accounting, strategic management accounting and accounting for advanced technologies have led to progress management accounting and various organizations.
\end{abstract}

Keywords: Management Accounting, Strategic Management Accounting, Accounting For Advanced Technologies, Activity Accounting

\section{Introduction}

In 1980 s, management accounting was improved so that it was a turning point for that, since in that decade mini computers became popular which operational technology and research was increasingly developed in management accounting and the most important point was that managers, particularly those of big organizations paid attention to three major constructs:

1. International competition and increasing globalization of operations

2. More emphasis on customer-orientation

3 . Increased product quality

In addition to these wonderful changes, management accountants struggled with serious and fundamental problems.

\section{Significant Management Challenges}

In early $1980 \mathrm{~s}$, techniques and operations in management accounting were not able to meet substantial and major needs of organizations especially organizations operating at global level. Even some accounting writer's e.g. Kaplan and Johnson criticized this condition and enumerated the most important challenges for management accounting $[1,7]$. The most important challenges are briefly as follows:

1. Not introducing new techniques in management accounting

2. Dominating management accounting

Management accounting which has been dominated by financial accounting is the second major challenge in countries especially in Iran. General, management accounting has been undermined by financial accounting reported outstandingly during past 60 years [15].

3. The lack of the relationship between theory and practice

4. The appearance of the management accounting

Forth challenge is related to appearance and evolution history of management accounting. Management accounting was affected by recession in 1980s. For instance Kaplan claimed that management accounting was not a new concept and its creation dated back to $19^{\text {th }}$ century [15]. Also, Johnson and Kaplan argued that most techniques of management accounting in 1980s were already discovered and introduced by $1925[7]$. 


\section{The Opportunities for Management Accounting}

The threats caused to communities and some accounting scholars to pursue interesting research in this field. Hence, Kaplan and Norton played significant role led to a revolution in management accounting [2]. He converts first, second and fourth challenges to new opportunities by introducing expansion of activity-based costing system and recommended field studies to solve the third challenge.

Bromwich and Bhimani analyzed experiences of firms in the field of introducing management accounting techniques [3]. Having surveyed various firms e.g. japans, Bromwich and Bhimani concluded that there was not positive evidence on the first challenge of the management accounting [3]. Although all industries did not employ new technologies, but some firms were creative and innovation in the field of providing management accounting techniques.

Finally, Bromwich and Bohemian concluded that management accounting did not need any revolution painted out by Kaplan et.al, so, that was a gradual evolution developed by using strategic management.

\section{Strategic Management Accounting Consists of 3 Methods}

1. Activity accounting

2. Strategic management accounting

3. Accounting for advanced manufacturing technologies

\subsection{Activity Accounting}

A. Activity -based costing (ABC)

B. Activity -based costing management (ABM)

C. Activity -based budgeting (ABB)

\section{Activity-Based Costing (ABC)}

In activity-based costing (ABC) systems, activities are real source of costs rather than products allocation of costs to products is done in two steps.

\section{Exhibit 1: Various Methods of Accounting for Strategic Positioning}

\section{Exhibit 2: All Components of Activity-Based Costing System}

\section{Exhibit 1}

\section{Activity Accounting (AA)}

A: Activity-based costing (ABC)

$\mathrm{B}$ : Activity-based management (ABM)

$\mathrm{C}$ : Activity-based budgeting (ABB)

\section{Strategic Management Accounting (SMA)}

\section{Accounting for Advanced Technology Manufacturing} (AAMT)

A: Total quality management (TQM)

B: Just in time (JIT)

$\mathrm{C}$ : Back flush costing (BFC)

\section{Activity-Based Costing Management (ABM)}

Activity-based costing system considered as subset of activity-based costing management (ABM) measures costs related to services and products and that is an industrial accounting method for determining accurate value of products or services. ABM determines relationship between incurred costs and corporate aims.

One is a technique of cost management expected to increase corporate profit ability. In this method, allocation of cost behaviors is employed as a basis of cost management of consumed resources.

\section{Activity-Based Budgeting (ABB)}

Activity-based costing management (ABM) was also source of activity-based budgeting (ABB) technique [4].

Exhibit 2- All Components of Activity-Based Costing System

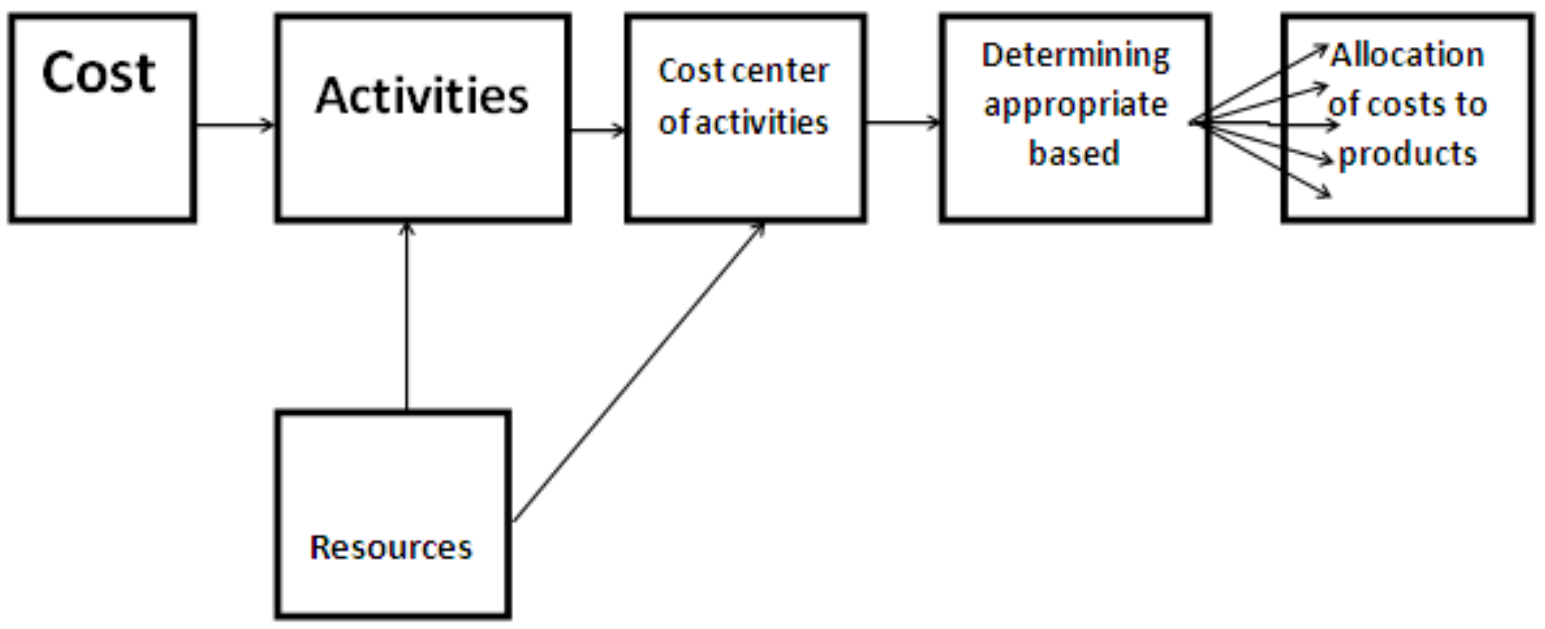




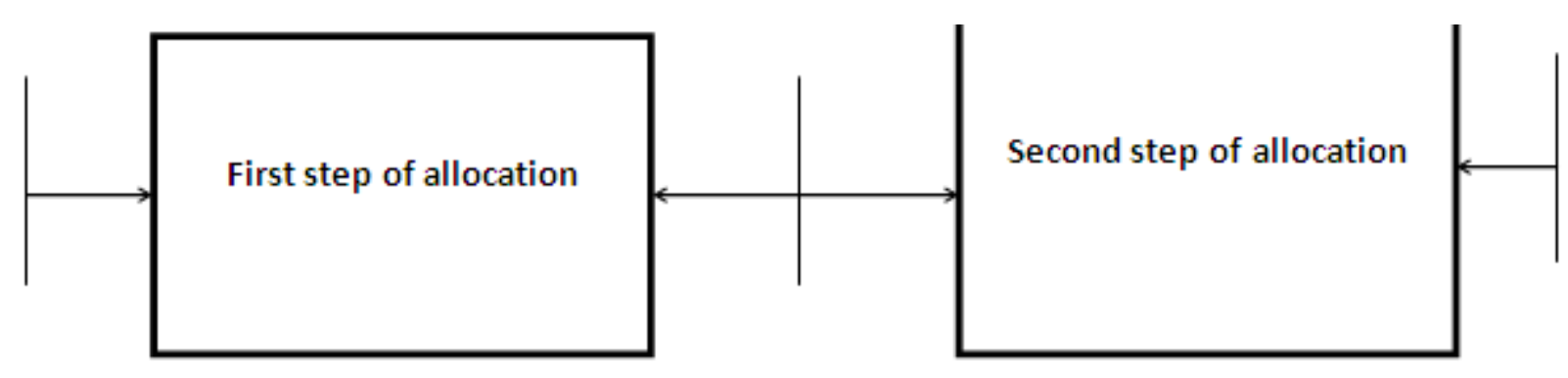

Reference: Mohammad Namazi,

Study of activity-based costing system in management accounting and its

behavioral considerations: studies of accounting and auditing, seventh year, no.26and27, winter 2008 and paring 2009, pp.71-106

\subsection{Strategic Management Accounting (SMA)}

Generally, strategic management accounting consists of collection, classification, participation and analysis of financial and non-financial information on operation of firm (exhibit3).

\section{Exhibit 3}

1. Financial and non-financial strategic information of major competitors of firm

2. Financial and non-financial strategic information of firm

3. Strategic management accounting

\section{In this respect, Strategic Management Accounting Plays \\ Four Essential Roles as Follows:}

1. Based on information about management accounting (particularly in the field of costs, prices, Sales quantity and market size, cash flow and access to financial resources for firm and its competitors), status and position of firm and in related industry can be determined.

2. Management accounting information can be employed to formulate future strategies of firm and also clarify the situation of corporate competitive advantages.

3. Provides necessary base to create a benchmark for optimal exploration of firm.

4. Uses relevant methods in relation to strategies already implemented in firm.

\section{Exhibit 4}

1. Creation of sustained competitive advantage

2. Financial and non-financial strategic information of major competitors of firm

3. Financial and non-financial strategic information of firm

4. Strategic management accounting

5. Strategic management accounting
Second advancement in the field of strategic management accounting stemmed from results from [5]. He emphasized that firms should access sustained competitive advantage in markets.

Third advance in strategic management accounting is provided by [12]. They followed Porter view, who believed that strategic management accounting not only encompass strategic information on firm, competitors and stable competitive advantage, but also include benefit of product for customer [5]. In their view, costs could be allocated to product benefits e.g. durability, high quality, ease to use, after-sale guarantee and product safety rather than to products.

\section{Thus Exhibit 5 may be presented in this respect:}

\section{Exhibit 5}

1. Benefit of product for customer

2. Creation of sustained competitive advantage

3. Financial and non-financial strategic information of major competitors of firm

4. Financial and non-financial strategic information of firm

5. Strategic management accounting

Final advancement in the field of strategic management accounting was achieved through target costing. Target costing being more popular in Japan is a systematic method to determine final price of product based on market standards and consists of three following steps C [13].

1. Identification of new products

2. Determination of target final price

$\mathrm{TC}=\mathrm{TS}-\mathrm{TP}$

TC $=$ TARGET FINAL PRICE PROFIT

TS $=$ TARGET SALESTP $=$ TARGET

3. Comparison of target final price to estimated final price for product based on current prices 
Main goal of target costing is to determine final price of new product before offering it to market . This final price could help firm to compete in marketing in a strategic way, This is achieved by studying value chain and reducing final price as well as product lifetime to a lower amount. While target costing is applying to new products, kaizen costing can be used for current products (exhibit 6).

\section{Exhibit 6}

1. Reduction of product lifetime

2. Creation of sustained competitive advantage

3. Financial and non-financial strategic information of major competitors of firm

4. Financial and non-financial strategic information of firm

Although all above methods are useful in applying strategic management accounting, it seems that kaizen costing or target costing are the most practical methods.

\subsection{Accounting for Advanced Manufacturing Technology (AAMT)}

The main goal of most techniques of accounting systems is improving appraisal of operations for advanced manufacturing technology (AAMT) in direct continuous reforms.

Johnson was the first researcher who mixed quality with activity accounting [8]. Then Maskell followed Johnson work and declared goal of global giant firm [11]. So, as a result defect products can decrease to zero, this led to increased competition in market.

Unlike quality accounting which deals with soft accounting information (qualitative items), back flush costing deals with hard accounting information [10].

Second appraisal technique is called strategic investment appraisal. Supporters of this technique (for instance Bronwich and Bhimani claim that despite of industrial methods, investments based on many costs and benefits have to explorer, although costs and benefits cannot be quantified in traditional accounting system, but there are strategic methods, which could be considered to analyze management accountants [3].

\section{Conclusion}

Management accounting succeeded to convert challenges to opportunities relying on major efforts of some writers and scholars [1, 2,9]. Management accounting extended by emphasis on accounting in three major fields as:

1. Activity accounting

2. Strategic management accounting

3. Accounting for advanced manufacturing technology (AAMT)

These three major fields promote future management accounting and refresh it. Consequently, as management accounting can go on extended services to various commercial, industrial and governmental unit scan adapt future management accounting with new technological and management accounting. In addition to, management accounting will be able to meet current needs of organizations and industries and fill gaps of several decades in formulation and introduction of new techniques. So, management accounting has to extend correspond to daily needs of society.

Honorable scholars in management accounting have to analyze new techniques, so that can take to account effects of cultural and operational aspects of techniques to solve practical problems and dilemmas.

Industries and organizations have to be equipped with new techniques of management accounting in order to employ them in practice as soon as possible.

\section{References}

[1] Kaplan R. S., (1983), Measuring Manufacturing Performance, A New Challenge to Management Accounting Research Accounting Review, 58/4: 686-705.

[2] Kaplan R. S., and Norton, D. P., (1992), The Balanced Scorecard Measures that Drive Performance, Harvard Business Review, 70/1 .71-79.

[3] Bromwich, M. and Bhimani, A., (1989) Management Accounting Evolution not Revolution Chartered Institute of Management Accountants London.

[4] Brimson, J., and Fraser, R., (1991) The Key Features of ABB, Management Accounting (UK), 69/1 42-43.

[5] Porter, M. E., (1980), Competitive Strategy, Techniques for Analyzing Industries and Competitors the Free Press, New York.

[6] Ittner, C. (1988) Texas Instruments Cost of Quality, pp. 240250, In R. Cooper and R. S. Kaplan (eds), The Design of cost Management systems, Prentice Hall, London.

[7] Johnson, H. T., and Kaplan. R. S., (1987), Relevance Lost, The Rise and fall of Management Accounting, Harvard Business School Press, Boston.

[8] Johnson, H.T., (1988), Activity - Based Information a blueprint for World - Class Management Accounting, Management Accounting (US), and 69/12:23-30.

[9] Bromwich, maksell M., and Bhimani, A., (1991) Strategic Investment Appraisal, Management Accounting (US) 72/9, 45-48.

[10] Homgren C. T., Dalar S. M., and Foster J., (2003) Cost Accounting, A Managerial Emphasis, 11 the edition Prentice- Hall New Jersey.

[11] Maskell, B. H., (1989), Performance Measurement for World Class Manufacturing, Management Accounting (UK), 67/5: 32-33.

[12] Shank J. K., and Govindarajan V., (1989), Strategic Cost Analysis, Irwin Inc., Homewood Illinois.

[13] Namazi Mohammad, winter 1998 and spring 1999,"Study of activity -based costing of management accounting and its behavioral considerations, studies of accounting and auditing" seventh year, $\mathrm{n}^{\circ}$. 26-27, PP 71-106. 
[14] Namazi Mohammad, 205, Industrial accounting (2), Budgeting and control of standard systems samt organization publishing, Tehran.
[15] Kaplan, R. S., (1984), The Evolution of Management Accounting, Accounting Review, 59/3: 390- 418. 